\title{
Cause of low arterial oxygen saturation in pulmonary fibrosis
}

\author{
J OH N H M E R ${ }^{1}$ \\ From the Medical Unit, King's College Hospital, London
}

Since the description of 'alveolar-capillary block' by Austrian, McClement, Renzetti, Donald, Riley, and Cournand (1951), impairment of diffusion across the alveolar-capillary membrane has been regarded as an important factor in the production of low arterial oxygen saturations in patients with diffuse pulmonary disease. However, Luchsinger, Moser, Bühlmann, and Rossier (1957) suggested that restriction of the capillary bed might be responsible, and the demonstration by Roughton and Forster (1957) that the relatively slow chemical reaction with haemoglobin was a major resistance to the absorption of respiratory gases lent support to this view. More recently, Motley (1958) and Finley, Swenson, and Comroe (1962) have shown the importance of uneven distribution of ventilation and perfusion in producing hypoxaemia.

In view of the doubt as to the importance of diffusion in gas absorption, Cotes (1963) has suggested the non-committal term 'transfer factor' instead of 'diffusing capacity' $\left(D_{L}\right)$ to describe the process. Roughton and Forster (1957) showed that it was possible to separate the red cell and the membrane components of gas transfer by making use of the competition between carbon monoxide and oxygen for the available haemoglobin (Fig. 1). This technique gives an estimate of the volume of the pulmonary capillaries $(\mathrm{Vc})$ if the rate of combination of the gas with blood $(\theta)$ is known. However, both the capillary volume (Vc) and the membrane component $\left(D_{M}\right)$ estimated in this way are probably influenced by uneven distribution effects (Hamer, 1963b) which limit the contact between alveolar gas and capillary blood. The relation between the factors is given by the formula

$$
\frac{1}{\mathrm{D}_{\mathrm{L}}}=\frac{1}{\mathrm{D}_{\mathrm{M}}}+\frac{1}{\hat{\theta} \mathrm{Vc}}
$$

In the present study, the technique of Roughton and Forster (1957) was used to analyse the process of gas transfer in seven patients with diffuse

\footnotetext{
1 Present address: Institute of Cardiology, 35 Wimpo:e Street,
} London W.1.

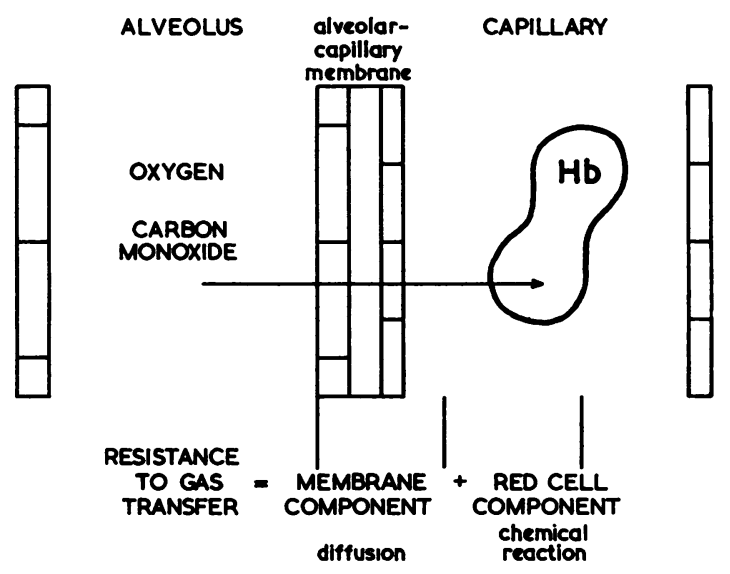

FIG. 1. Diagrammatic representation of the absorption of $\mathrm{O}_{2}$ and $\mathrm{CO}$ in the lungs. The gases diffuse across the alveolar-capillary membrane and combine with haemoglobin in the red cells of the pulmonary capillaries. The competition between the two gases can be used to separate the membrane and the red cell components of the process.

interstitial pulmonary fibrosis and two with diffuse metastatic carcinoma of the lung. The findings are compared with the changes reported in 30 patients with pulmonary sarcoidosis (Hamer, 1963a). Cardiac catheterization was performed in four of the patients with interstitial pulmonary fibrosis and four of the sarcoidosis group, three of these patients having radiological evidence of fibrosis in addition to infiltration in the lungs.

\section{METHODS}

The measurement of the components of gas transfer in these patients was performed in the same way as in the study of pulmonary sarcoidosis (Hamer, 1963b). The single-breath technique described by Ogilvie. Forster, Blakemore, and Morton (1957) was used. with some modifications, to measure the carbon monoxide uptake at two levels of oxygen tension in each subject. After a full but unforced expiration, a 
maximal breath of gas containing approximately $0 \cdot 2 \%$ $\mathrm{CO}$ and $15 \%$ helium was inspired and held for about 10 seconds. Two gas mixtures were used, one made up in pure $\mathrm{O}_{2}$ and the other with $20 \% \mathrm{O}_{2}$ and the remainder $\mathrm{N}_{2}$ (referred to as the 'air' mixture). Straining during breath-holding was avoided as much as possible. A single three-way tap was used to reduce the dead space of the apparatus. Rubber bags were applied to the outlet of the tap, using tapered airtight connectors. and were then evacuated by a suction line. A sample was collected after the expiration of about 1 litre to flush out the dead space. Unduly forceful expiration was avoided, and the sampling time was kept as small as possible. In general, approximately 1 litre of expirate was collected in about half a second.

Part of each sample was transferred to a mercury tonometer for the subsequent measurement of $\mathrm{O}_{2}$ and $\mathrm{CO}_{2}$ content by the Scholander method. The remainder of the sample was then drawn through a $\mathrm{CO}_{2}$ absorber to the gas analysers at approximately $0.51 . / \mathrm{min}$. The gas to be inspired was drawn through a humidifier to the analysers before each estimation. Approximately 0.5 litre of gas was needed for accurate measurement of $\mathrm{CO}$ and $\mathrm{He}$. The gas passed first to a Cambridge catharometer set to read $\mathrm{He}$ concentrations in moist air. The catharometer readings were corrected for variations in oxygen content on the basis of a reading of $1.9 \% \mathrm{He}$ with $100 \% \mathrm{O}_{2}$, assuming a linear increase in the reading between $21 \%$ and $100 \% \mathrm{O}_{2}$ in the gas carrying the helium. After passing through a water absorber (magnesium perchlorate), the gas passed through a $\mathrm{CO}$ analyser (type SCLA). ${ }^{1}$ This instrument was calibrated before each study with a standard gas mixture supplied by the makers. One scale, extending from 0.03 to $0.25 \%$ $\mathrm{CO}$. was used for measurement of both the inspired and expired gas, and the linearity of the response was confirmed by comparison with the catharometer readings, using serial dilutions of mixtures of $\mathrm{CO}$ and He. All measurements were made as soon as the instruments had reached a steady reading after flow had stopped. The $\mathrm{CO}$ and $\mathrm{He}$ contents of the expired sample were corrected for the $\mathrm{CO}_{2}$ absorbed.

The duration of breath-holding and the volume of gas inspired were obtained from the spirometer chart. Breath-holding was measured from the beginning of inspiration to the beginning of sample collection, and the value was corrected as suggested by Jones and Meade (1961), i.e., half the sampling time was added and three-tenths of the inspiratory time subtracted, to allow for variations in the timing of inspiration and expiration. The effective lung capacity during breath-holding was calculated from the dilution of the inspired He, as suggested by McGrath and Thomson (1959), after subtraction of an estimated value for the dead space. The effective capacity calculated in this way is preferred to the total capacity as measured by the closed-circuit method or by body plethysmography as it gives a better estimate of the volume of

${ }_{1}^{1}$ Infra Red Development Co. lung taking part in the absorption of $\mathrm{CO}$ from the single breath.

Measurements with the oxygen mixture were performed first in each subject to minimize the correction necessary for the progressive increase in circulating carboxyhaemoglobin. The pulmonary capillary carbon monoxide concentration was estimated by equilibration at high oxygen tensions before and after each study. An equilibrated sample was obtained after a preliminary period breathing oxygen by rebreathing for four minutes in a 6-litre closed circuit filled with oxygen and containing a $\mathrm{CO}$. absorber (Siösteen and Sjöstrand, 1951). Values for each experiment were obtained by interpolation and corrected to the appropriate $\mathrm{P}_{\mathrm{O}_{2}}$ by direct proportion. The estimated pulmonary capillary $\mathrm{CO}$ concentration was subtracted from both the initial and final alveolar $\mathrm{CO}$ concentrations before calculation of the diffusing capacity. A small further correction was made to the initial concentration for the $\mathrm{CO}$ in the residual volume before each experiment.

The rate of uptake of $\mathrm{CO}$ by the blood $(\theta)$ was calculated for each experiment from the relation $\frac{1}{\theta}=$ $0 \cdot 33+0.0057 \mathbf{P}_{\mathbf{O}_{2}}$ obtained from Fig. 1 of Roughton and $\AA$ Forster (1957) for $\lambda=\infty$, i.e., on the assumption that there is no increase in the resistance to gas transfer at the red cell surface. Recent work shows no evidence of such a resistance in vivo (Thews and Niesel, 1959 ; Kreuzer and Yahr, 1960 ; Sirs. 1963). The appropriate $\mathrm{P}_{\mathrm{O}_{2}}$ was obtained, as suggested by McNeill, Rankin, and Forster (1958), by adding 5 $\mathrm{mm}$. $\mathrm{Hg}$ to the $\mathrm{P}_{\mathrm{O}_{2}}$ of the expired sample to give an estimate of the mean alveolar $\mathrm{P}_{\mathrm{O}_{2}}$, and subtracting the alveolar-capillary oxygen difference estimated as $\dot{\mathrm{V}}_{\mathrm{O}_{2}} \div \mathrm{D}_{\mathrm{LO}_{2}}$. Oxygen uptake $\left(\dot{\mathrm{V}}_{\mathrm{O}_{2}}\right)$ was taken from tables, assuming a metabolic rate $20 \%$ above basal, and $\mathrm{D}_{\mathrm{LO}_{2}}$ was assumed to be 1.23 times $\mathrm{D}_{\mathrm{LCo}}$. The value obtained for $\theta$ was corrected proportionately for changes in the venous haematocrit.

Two or three measurements of $\mathrm{D}_{\mathrm{L}}$ and $\theta$ were obtained at both levels of oxygen tension in most of these subjects, and the mean values were used in the subsequent calculations. The membrane component of carbon monoxide transfer $\left(D_{M}\right)$ and the pulmonary capillary volume $(\mathrm{Vc})$ were obtained from the simultaneous equations $\frac{1}{\mathrm{~L}_{\mathrm{L}}}-\frac{1}{\mathrm{D}_{\mathrm{M}}}+\frac{1}{\theta \cdot \mathrm{V}_{\mathrm{C}}}$ at each oxygen tension. A standard value for the transfer factor $\left(D_{L}\right)$ at an oxygen tension of about $120 \mathrm{~mm}$. $\mathrm{Hg}$ was obtained by putting $\theta=1$. The graphical solution of the equation is shown in Fig. 2 in which $\frac{1}{D_{L}}$ is plotted against $\frac{1}{\theta}$ which is linearly related to $\mathrm{P}_{\mathrm{O}_{2}}$. The transfer factors $\left(D_{L}\right.$ and $\left.D_{M}\right)$ are expressed throughout in $\mathrm{ml}$./ $\mathrm{mm}$. $\mathrm{Hg} / \mathrm{min}$., $\theta$ in $\mathrm{ml}$. $\mathrm{CO} / \mathrm{ml}$. blood $/ \mathrm{mm}$. $\mathrm{Hg} / \mathrm{min}$., and capillary volume $(\mathrm{Vc})$ in millilitres. Values more than three standard errors from the regression for age in normal subjects (Hamer. 1962) were regarded 


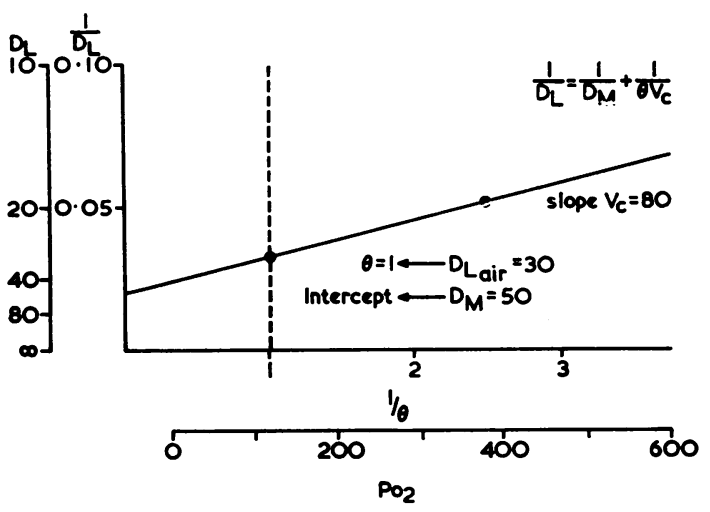

FIG. 2. Graphical calculation of $D_{M}$ and $V_{C} \cdot \frac{1}{D_{L}}$ is plotted against $\frac{1}{\theta}$, which varies linearly with oxygen tension. As the oxygen tension is increased, $\frac{1}{\theta}$ becomes

larger and $D_{L}$ is reduced. The slope of the line joining observations at two different oxygen tensions gives the capillary volume $\left(V_{C}\right)$. The intercept gives the membrane component $\left(D_{M}\right)$. A standard value for $D_{L}$ is obtained at $\theta=1$.

as abnormal. Lung volumes were expressed as percentages of the values predicted for residual volume and vital capacity in Table $X$ of Needham, Rogan, and McDonald (1954), corrected to B.T.P.S.

Cardiac catheterization was carried out under basal conditions without sedation. Pressure measurements were referred to a base line at the middle of the chest at the level of the fourth costal cartilage. Cardiac output was determined from the Fick principle, using oxygen saturations obtained with a Kipp reflection oximeter and estimating oxygen consumption from tables at $10 \%$ above the basal level. The pulmonary vascular resistance was calculated using the pulmonary artery wedge pressure as an estimate of pulmonary venous pressure. In three patients the catheter could not be wedged; the pulmonary venous pressure in these patients was assumed to be similar to that in the other cases studied. The contact time between blood and alveolar gas in the pulmonary capillaries was calculated from the relation between capillary volume and flow $(\mathrm{t}(\mathrm{sec})=\mathrm{Vc}(\mathrm{ml}.) \div \dot{\mathrm{Q}} \mathrm{c}(\mathrm{ml} . / \mathrm{sec})$.$) .$

\section{RESULTS}

LUNG VOLUMES The age and physical characteristics of each patient are described in Table $I$. All but W. L. and E. F. were non-smokers. The effective lung capacity obtained from the dilution of helium in each single-breath test is shown in Table II. The results obtained using the two different gas mixtures are similar, providing
TABLE I

PHYSICAL DATA

\begin{tabular}{|c|c|c|c|c|c|c|}
\hline Patient & $\begin{array}{l}\text { Age } \\
(y r)\end{array}$ & Sex & $\begin{array}{c}\text { Height } \\
\text { (in.) }\end{array}$ & $\begin{array}{l}\text { Weight } \\
\text { (lb.) }\end{array}$ & $\underset{\text { (m. }{ }^{2} \text { ) }}{\text { B.S.A. }}$ & $\begin{array}{c}\text { Haemo- } \\
\text { globin } \\
(\mathrm{g} . \\
100 \mathrm{ml} .)\end{array}$ \\
\hline $\begin{array}{l}\text { Pulmonary } \\
\text { C.M. } \\
\text { R.G. } \\
\text { J.D. } \\
\text { W.L. } \\
\text { A.L. } \\
\text { M.G.* } \\
\text { E.F. }\end{array}$ & $\begin{array}{c}\text { rosis } \\
25 \\
30 \\
72 \\
59 \\
71 \\
47 \\
63\end{array}$ & $\begin{array}{l}\mathbf{M} \\
\mathbf{M} \\
\mathbf{M} \\
\mathbf{M} \\
\mathbf{F} \\
\mathbf{F} \\
\mathbf{M}\end{array}$ & $\begin{array}{l}67 \\
68 \\
71 \\
70 \\
62 \\
59 \\
67\end{array}$ & $\begin{array}{l}119 \\
177 \\
186 \\
145 \\
105 \\
120 \\
125\end{array}$ & $\begin{array}{l}1.62 \\
1.96 \\
2.04 \\
1.82 \\
1.45 \\
1.48 \\
1.64\end{array}$ & $\begin{array}{l}13.9 \\
14 \cdot 4 \\
14 \cdot 8 \\
14.9 \\
12 \cdot 8 \\
12.7 \\
15 \cdot 1\end{array}$ \\
\hline $\begin{array}{c}\text { Diffuse ca } \\
\text { L.C. } \\
\text { W.C. }\end{array}$ & $\begin{array}{r}10 m a \\
62 \\
56\end{array}$ & $\begin{array}{l}\mathbf{M} \\
\mathbf{M}\end{array}$ & $\begin{array}{l}67 \\
59\end{array}$ & $\begin{array}{l}175 \\
120\end{array}$ & $\begin{array}{l}1.91 \\
1.48\end{array}$ & $\begin{array}{l}15 \cdot 5 \\
12 \cdot 7\end{array}$ \\
\hline
\end{tabular}

confirmation of the accuracy of the correction of the helium reading for changes in the oxygen content of the gas. The effective lung capacities for a series of tests in any given subject show little variation, the range being less than $15 \%$ of the total capacity. The effective residual volume measurements follow a similar pattern.

The patients with pulmonary fibrosis show a considerable reduction of effective lung capacity and residual volume, the average lung capacity being $58 \%$ and the residual volume $68 \%$ of the predicted value (Table III). The two patients with diffuse carcinomatous infiltration had grossly reduced effective lung volumes, the total capacity averaging $37 \%$ and the residual volume $26 \%$ of predicted.

GAS TRANSFER The values obtained for the transfer factor $\left(D_{L}\right)$ and the corresponding measurements of $\theta$ in each subject are shown in Table II, and the calculated values for the transfer factor $\left(D_{L}, \theta=1\right)$, the membrane component $\left(D_{M}\right)$, and the pulmonary capillary volume (Vc) are given in Table III. In the patients with pulmonary fibrosis, the transfer factor $\left(D_{L}\right)$ was more than three standard errors below the normal for the patient's age (Hamer, 1962). The membrane component $\left(\mathrm{D}_{\mathbf{M}}\right)$ was similarly reduced in all cases, but the capillary volume (Vc) was less affected, being in the normal range in two subjects. The patient (E.F.) with the largest capillary volume appeared to be less severely affected than the other patients in this group, as the radiographic changes were minimal. There was no clear relationship between the changes in gas transfer and the severity of the disease as judged from the reduction in lung volume. The two patients with diffuse carcinoma had a gross reduction of both components of gas transfer. 
TABLE II GAS TRANSFER MEASUREMENTS AND EFFECTIVE LUNG VOLUMES

\begin{tabular}{|c|c|c|c|c|c|c|c|c|}
\hline \multirow{3}{*}{ Patient } & \multicolumn{4}{|c|}{ Air Mixture } & \multicolumn{4}{|c|}{ Oxygen Mixture } \\
\hline & \multirow{2}{*}{10} & \multirow{2}{*}{$\mathrm{D}_{\mathrm{L}}$} & \multicolumn{2}{|c|}{ Effective Lung Volumes } & \multirow{2}{*}{10} & \multirow{2}{*}{$\mathrm{D}_{\mathrm{L}}$} & \multicolumn{2}{|c|}{ Effective Lung Volumes } \\
\hline & & & $\begin{array}{c}\text { T.L.C. } \\
(\mathrm{ml} .)\end{array}$ & $\begin{array}{l}\text { R.V. } \\
\text { (ml.) }\end{array}$ & & & $\underset{(\mathrm{ml} .)}{\text { T.L.C. }}$ & $\begin{array}{l}\text { R.V. } \\
\text { (ml.) }\end{array}$ \\
\hline C.M. & $\begin{array}{l}0.66 \\
0.64 \\
0.66\end{array}$ & $\begin{array}{l}9 \cdot 5 \\
8 \cdot 2 \\
9 \cdot 6\end{array}$ & $\begin{array}{l}1,800 \\
1,860 \\
1,800\end{array}$ & $\begin{array}{l}740 \\
800 \\
760\end{array}$ & $\begin{array}{l}2 \cdot 10 \\
2 \cdot 04 \\
2 \cdot 06\end{array}$ & $\begin{array}{l}6 \cdot 8 \\
6 \cdot 3 \\
6 \cdot 4\end{array}$ & $\begin{array}{l}1,870 \\
1,840 \\
1,720\end{array}$ & $\begin{array}{l}670 \\
720 \\
610\end{array}$ \\
\hline R.G. & $\begin{array}{l}0.76 \\
0.76 \\
0.76\end{array}$ & $\begin{array}{l}8 \cdot 5 \\
8 \cdot 8 \\
8 \cdot 7\end{array}$ & $\begin{array}{l}3,200 \\
3,290 \\
3,090\end{array}$ & $\begin{array}{l}1,600 \\
1,650 \\
1,530\end{array}$ & $\begin{array}{l}1.93 \\
1.91\end{array}$ & $\begin{array}{l}5 \cdot 1 \\
4 \cdot 8\end{array}$ & $\begin{array}{l}3,220 \\
3,140\end{array}$ & $\begin{array}{l}1,620 \\
1,640\end{array}$ \\
\hline J.D. & $\begin{array}{l}1 \cdot 10 \\
0 \cdot 83\end{array}$ & $\begin{array}{l}13.4 \\
12.8 \\
\end{array}$ & $\begin{array}{l}5,700 \\
5,970\end{array}$ & $\begin{array}{l}1,980 \\
2,070\end{array}$ & $\begin{array}{l}2 \cdot 33 \\
2 \cdot 61\end{array}$ & $\begin{array}{l}9 \cdot 6 \\
7 \cdot 1 \\
\end{array}$ & $\begin{array}{l}5,760 \\
6,040\end{array}$ & $\begin{array}{l}2,430 \\
2,000\end{array}$ \\
\hline W.L. & $\begin{array}{l}0.96 \\
0.95\end{array}$ & $\begin{array}{l}13 \cdot 6 \\
13 \cdot 2\end{array}$ & $\begin{array}{l}5,670 \\
5,700\end{array}$ & $\begin{array}{l}2,550 \\
2,600 \\
\end{array}$ & $\begin{array}{l}2 \cdot 38 \\
2 \cdot 36 \\
\end{array}$ & $\begin{array}{l}8 \cdot 9 \\
9 \cdot 0 \\
\end{array}$ & $\begin{array}{l}5,530 \\
5,360 \\
\end{array}$ & $\begin{array}{r}2,400 \\
2,350 \\
\end{array}$ \\
\hline A.L. & 0.83 & $5 \cdot 2$ & 1,810 & 1,130 & 1.98 & $3 \cdot 7$ & 1,740 & 1,080 \\
\hline M.G. & $\begin{array}{l}1.08 \\
1.06 \\
\end{array}$ & $\begin{array}{l}15 \cdot 1 \\
15 \cdot 5 \\
\end{array}$ & $\begin{array}{l}3,150 \\
3,070 \\
\end{array}$ & $\begin{array}{l}1,320 \\
1,360 \\
\end{array}$ & $\begin{array}{l}2 \cdot 90 \\
2 \cdot 81\end{array}$ & $\begin{array}{l}9 \cdot 1 \\
8 \cdot 9\end{array}$ & $\begin{array}{l}3,070 \\
2,920 \\
\end{array}$ & $\begin{array}{l}1,230 \\
1,210\end{array}$ \\
\hline E.F. & $\begin{array}{l}0.95 \\
0.91 \\
\end{array}$ & $\begin{array}{l}14 \cdot 5 \\
14 \cdot 3 \\
\end{array}$ & $\begin{array}{l}5,4 \in 0 \\
5,070 \\
\end{array}$ & $\begin{array}{l}1,970 \\
2,370 \\
\end{array}$ & $\begin{array}{l}2 \cdot 76 \\
2 \cdot 81 \\
\end{array}$ & $\begin{array}{l}10 \cdot 7 \\
10 \cdot 4\end{array}$ & $\begin{array}{l}5,570 \\
5,490\end{array}$ & $\begin{array}{l}1,880 \\
1,810\end{array}$ \\
\hline L.C. & $\begin{array}{l}0.74 \\
0.73 \\
\end{array}$ & $\begin{array}{l}4 \cdot 8 \\
4 \cdot 9 \\
\end{array}$ & $\begin{array}{l}2,420 \\
2,420\end{array}$ & $\begin{array}{l}840 \\
750 \\
\end{array}$ & $\begin{array}{l}1.94 \\
1.74 \\
\end{array}$ & $\begin{array}{l}3 \cdot 1 \\
3 \cdot 1 \\
\end{array}$ & $\begin{array}{l}2,260 \\
2,230\end{array}$ & $\begin{array}{l}760 \\
590\end{array}$ \\
\hline W.C. & $\begin{array}{l}0.71 \\
0.71\end{array}$ & $\begin{array}{l}8 \cdot 4 \\
8 \cdot 1\end{array}$ & $\begin{array}{l}2,520 \\
2,390\end{array}$ & $\begin{array}{l}770 \\
710\end{array}$ & $\begin{array}{l}1 \cdot 23 \\
1 \cdot 22\end{array}$ & $\begin{array}{l}6 \cdot 2 \\
6 \cdot 6\end{array}$ & $\begin{array}{l}2,330 \\
2,170\end{array}$ & $\begin{array}{l}570 \\
520\end{array}$ \\
\hline
\end{tabular}

TABLE III

RESULTS

\begin{tabular}{|c|c|c|c|c|c|c|c|}
\hline \multirow{3}{*}{ Patient } & \multicolumn{4}{|c|}{ Fffective Lung Volumes } & \multicolumn{3}{|c|}{ Gas Transfer Measurements } \\
\hline & \multicolumn{2}{|c|}{ T.L.C. } & \multicolumn{2}{|c|}{ R.V. } & \multirow{2}{*}{$\begin{array}{c}\mathrm{D}_{1} \theta=1 \\
(\mathrm{ml} . \mathrm{mm} . \\
\mathrm{Hg} \min .)\end{array}$} & \multirow{2}{*}{$\begin{array}{c}\mathrm{D}_{\mathbf{m}} \\
\text { (ml. mm. } \\
\mathrm{Hg} \text { min.) }\end{array}$} & \multirow{2}{*}{$\begin{array}{c}V_{c} \\
(m i .)\end{array}$} \\
\hline & (ml. B.T.P.S.) & $\%$ Predicted & (ml. B.T.P.S.) & $\%$ Predicted & & & \\
\hline $\begin{array}{l}\text { C.M. } \\
\text { R.G. } \\
\text { J.D. } \\
\text { W.L. } \\
\text { A.L. } \\
\text { M.G. } \\
\text { E.F. } \\
\text { L.C. } \\
\text { W.C. }\end{array}$ & $\begin{array}{l}1,810 \\
3,180 \\
5,880 \\
3,090 \\
1,780 \\
3,000 \\
5,400 \\
2,330 \\
2,350\end{array}$ & $\begin{array}{l}26 \\
48 \\
89 \\
45 \\
43 \\
73 \\
84 \\
39 \\
34\end{array}$ & $\begin{array}{r}770 \\
1,610 \\
2,120 \\
2,480 \\
1,100 \\
1,260 \\
2,000 \\
730 \\
650\end{array}$ & $\begin{array}{l}38 \\
89 \\
71 \\
83 \\
56 \\
73 \\
67 \\
30 \\
21\end{array}$ & $\begin{array}{r}8 \cdot 3 \\
7 \cdot 5 \\
13 \cdot 1 \\
13 \cdot 2 \\
4 \cdot 3 \\
15 \cdot 3 \\
14 \cdot 2 \\
4 \cdot 2 \\
7 \cdot 0\end{array}$ & $\begin{array}{r}11 \\
18 \\
21 \\
20 \\
7 \\
26 \\
18 \\
8 \\
13\end{array}$ & $\begin{array}{l}33 \\
13 \\
30 \\
38^{*} \\
15 \\
29 \\
72^{*} \\
10 \\
15\end{array}$ \\
\hline
\end{tabular}

* Within three standard errors of normal for age.

The average values in each group, together with the average findings in 25 normal subjects (Hamer, 1962) and in three groups of patients with pulmonary sarcoidosis (Hamer, 1963b), are shown in Table IV. The results of the present study resemble those reported in the more severely affected patients with pulmonary sarcoidosis. Similar findings have been reported by McNeill et al. (1958) in five patients, and by Bates, Varvis, Donevan, and Christie (1960) in four patients using a slightly different technique.

PULMONARY CIRCULATION Cardiac catheterization was performed in four patients with diffuse
TABLE IV

AVERAGE VALUES FOR THE COMPONENTS OF GAS ๙ু TRANSFER

\begin{tabular}{|c|c|c|c|}
\hline 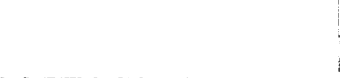 & $\begin{array}{l}\mathrm{D}_{\mathrm{L}} \theta=1 \\
(\mathrm{ml} . / \mathrm{mm} \\
\mathrm{Hg} / \mathrm{min} .)\end{array}$ & $\begin{array}{c}\mathrm{D}_{\mathrm{M}} \\
(\mathrm{mil} / \mathrm{mm} \text {. } \\
\mathrm{Hg} / \mathrm{min} .)\end{array}$ & $\begin{array}{l}V_{c} \\
(\mathrm{ml})\end{array}$ \\
\hline 25 normal subjects (Hamer, 1962) & $29 \cdot 4$ & 52 & 75 \\
\hline $\begin{array}{l}\text { Pulmonary sarcoidosis (Hamer, } \\
\text { 1963b) } \\
\text { Normal findings, } 7 \text { subjects } . . \\
\text { Low } D_{m} \text { only, } 16 \text { subjects } \ldots \\
\text { Low } D_{M} \text { and } V_{c}, 7 \text { subjects } \ldots\end{array}$ & $\begin{array}{l}27 \cdot 7 \\
16 \cdot 6 \\
10 \cdot 8\end{array}$ & $\begin{array}{l}49 \\
24 \\
21\end{array}$ & $\begin{array}{l}68 \\
55 \\
21\end{array}$ \\
\hline $\begin{array}{l}\text { Present study } \\
\text { Pulmonary fibrosis, } 7 \text { subjects } \\
\text { Diffuse carcinoma, } 2 \text { subjects }\end{array}$ & $\begin{array}{r}10.9 \\
5.6\end{array}$ & $\begin{array}{l}17 \\
11\end{array}$ & $\begin{array}{l}33 \\
13\end{array}$ \\
\hline
\end{tabular}


TABLE V

FINDINGS AT CARDIAC CATHETERIZATION

\begin{tabular}{|c|c|c|c|c|c|c|c|c|c|}
\hline Patient & Diagnosis & $\begin{array}{c}\text { Effective } \\
\text { Lung } \\
\text { Capacity } \\
\text { (\% } \% \\
\text { predicted) }\end{array}$ & $\begin{array}{c}\text { Arterial } \\
\mathrm{O}_{2} \underset{(\%)}{\text { Satn. }}\end{array}$ & $\begin{array}{c}\text { Cardiac } \\
\text { Output } \\
\left.\text { (1. } \min . \mathrm{m}^{2}{ }^{2}\right)\end{array}$ & $\begin{array}{c}\text { P.A. } \\
\text { Pressure } \\
\underset{\text { (mm.Hg) }}{\ddagger}\end{array}$ & $\begin{array}{c}\text { Mean } \\
\text { Wedge } \\
\text { Pressure } \\
\underset{f}{\ddagger} \text { mm.Hg) }\end{array}$ & $\begin{array}{l}\text { Pulmonary } \\
\text { Vascular } \\
\text { Resistance } \\
\text { (units.m.2) }\end{array}$ & $\begin{array}{c}\text { Capillary } \\
\text { Volume } \\
\left(\mathrm{ml} . / \mathrm{m} .^{2}\right)\end{array}$ & $\begin{array}{l}\text { Contact } \\
\text { Time } \\
\text { (sec.) }\end{array}$ \\
\hline $\begin{array}{l}\text { C.M. } \\
\text { R.G. } \\
\text { A.L. } \\
\text { M.G. }\end{array}$ & $\begin{array}{l}\text { I.P.F. } \\
\text { I.P.F. } \\
\text { I.P.F. } \\
\begin{array}{c}\text { Systemic } \\
\text { sclerosis }\end{array}\end{array}$ & $\begin{array}{l}26 \\
48 \\
43 \\
73\end{array}$ & $\begin{array}{l}84 \\
97 t \\
82 \\
93\end{array}$ & $\begin{array}{l}3 \cdot 0 \\
3 \cdot 2 \\
2 \cdot 9 \\
3 \cdot 7\end{array}$ & $\begin{array}{l}30 / 20 \\
25 / 10 \\
38 / 10 \\
75 / 25\end{array}$ & $\begin{array}{r}1 \\
2 \\
-3 \\
2\end{array}$ & $\begin{array}{r}8 \\
3 \\
7 \\
11\end{array}$ & $\begin{array}{r}20 \\
7 \\
10 \\
20\end{array}$ & $\begin{array}{l}0.4 \\
0.1 \\
0.2 \\
0.3\end{array}$ \\
\hline $\begin{array}{l}\text { T.M. } \\
\text { R.R. } \\
\text { G.W. } \\
\text { K.S. }\end{array}$ & $\begin{array}{l}\text { Sarcoid* } \\
\text { Sarcoid } \\
\text { Sarcoid } \\
\text { Sarcoid }\end{array}$ & $\begin{array}{l}70 \\
66 \\
60 \\
80\end{array}$ & $\begin{array}{l}88 \\
90 \\
86 \\
86\end{array}$ & $\begin{array}{l}4 \cdot 1 \\
3 \cdot 5 \\
2 \cdot 5 \\
4 \cdot 1\end{array}$ & $\begin{array}{l:l}46 / 18 \\
44 / 20 \\
55 / 30 \\
44 / 19\end{array}$ & $\frac{1}{-}$ & $\begin{array}{r}6 \\
7 \\
17 \\
7\end{array}$ & $\begin{array}{r}21 \\
8 \\
10 \\
44\end{array}$ & $\begin{array}{l}0 \cdot 3 \\
0 \cdot 1 \\
0 \cdot 2 \\
0 \cdot 6\end{array}$ \\
\hline
\end{tabular}

* Chest radiograph showed infiltration only. +94 on effort. $¥$ Base line at mid chest. I.P.F. =Interstitial pulmonary fibrosis.

pulmonary fibrosis and in four with sarcoidosis (Table V); the gas transfer measurements in the patients with sarcoidosis have been reported elsewhere (Hamer, 1963b). There was only slight elevation of pulmonary artery pressures in most of these patients, with a corresponding slight increase in pulmonary vascular resistance. In two cases the pulmonary hypertension was appreciable, and the resistance exceeded 10 units (expressed in terms of body surface area). The cardiac output was normal or slightly reduced, and there was no evidence of cardiac failure though some patients showed a prominent ' $a$ ' wave in the right atrial pressure-pulse. The arterial oxygen saturation was reduced at rest in all but one patient, and in this subject there was a clear fall in saturation on effort.

There is no correlation between the severity of the respiratory disease, as judged from the reduction in effective lung capacity, and the vascular

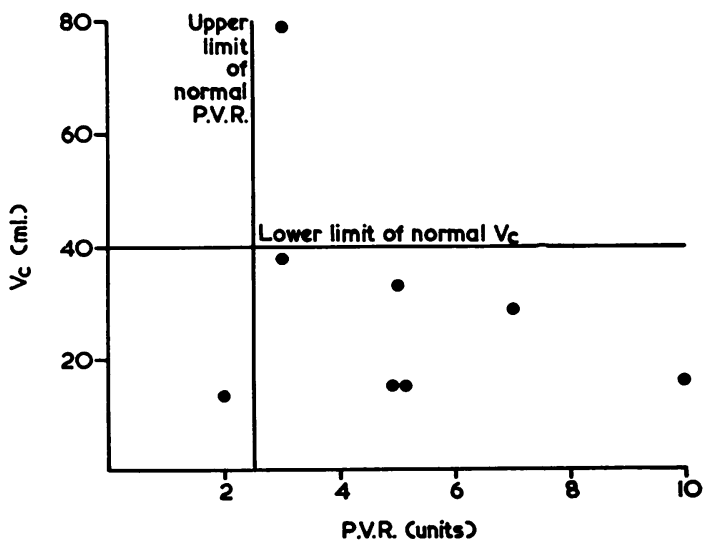

FIG. 3. Relation between pulmonary capillary volume $\left(V_{C}\right)$ and pulmonary vascular resistance (P.V.R.) in eight patients with diffuse pulmonary fibrosis. changes. Although the pulmonary vascular resistance and capillary volume were abnormal in all but two patients (R.G. and K.S. respectively) there was no definite relation between these two factors within the group (Fig. 3). Similarly, changes in the cardiac output and the arterial oxygen saturation appeared to be independent of the other parameters studied. The contact time was considerably reduced in most patients but was largely determined by the changes in capillary volume, as the pulmonary capillary blood flow was relatively unchanged. The average contact time was $0.3 \mathrm{sec}$.

\section{DISCUSSION}

Idiopathic pulmonary fibrosis was first described in an acute form by Hamman and Rich (1944). Baldwin, Cournand, and Richards (1949) studied the functional changes produced by pulmonary fibrosis and found a reduction in the volume of the lungs, a low arterial oxygen saturation, and evidence of hyperventilation. Austrian et al. (1951) suggested that the abnormality in these patients was due to 'alveolar-capillary block', i.e., impairment of diffusion of gases from the alveoli to the pulmonary capillaries. Subsequent work extended the definition of idiopathic pulmonary fibrosis to include chronic cases (Rubin and Lubliner, 1957 ; Scadding, 1960 ; Livingstone, Lewis, Reid, and Jefferson, 1964). It appeared to confirm the hypothesis of a diffusion defect (Marks, Cugell, Cadigan, and Gaensler, 1957) both in the idiopathic cases and in pulmonary fibrosis due to sarcoidosis (Marshall, Smellie, Baylis, Hoyle, and Bates, 1958) or scleroderma (Catterall and Rowell, 1963), and also in diffuse carcinomatous infiltration of the lungs (Baldwin et al., 1949).

The suggestion that a diffusion defect was responsible for the low arterial oxygen saturation in pulmonary fibrosis was first seriously 
challenged by Swiss workers (Rossier, Bühlmann, and Luchsinger, 1954 ; Luchsinger et al., 1957 ; Luchsinger, Katz, McCormick, Donohoe, and Moser, 1959). They pointed out that the hypoxaemia was associated with a rise in the pulmonary vascular resistance and suggested that a critical reduction in the pulmonary vascular bed was responsible for both changes. A small pulmonary capillary bed in the presence of a normal cardiac output would be expected to reduce the contact time between the red cells and the alveolar gas so that equilibrium could not be attained before the red cells reached the end of the capillary.

The work of Roughton and Forster (1957) has allowed a more accurate assessment of the importance of changes in the pulmonary capillary bed. They demonstrated the importance of the rate of combination of the gas with blood $(\theta)$ and showed that the capillary volume could be calculated using carbon monoxide. Unfortunately, the study of oxygen transfer is more difficult as there is no simple relation between $\theta$ for oxygen and the oxygen tension (Staub, Bishop, and Forster, 1962). Recent calculations, however, confirm the importance of a reduction in the contact time in the production of low arterial oxygen saturations, and suggest that in normal subjects equilibrium with alveolar gas is reached before the end of the capillaries except on exercise breathing a hypoxic gas mixture (Staub, 1963). These estimates are based on the assumption that the capillary volume calculated using carbon monoxide is also applicable to oxygen transfer. However, it has been suggested (Turino, Bergofsky, Goldring, and Fishman, 1963) that the capillary volume for oxygen may be smaller than for carbon monoxide as slow-moving oxygenated blood will take up carbon monoxide but not oxygen. However, this effect is unlikely to be large enough to affect the argument, and Staub (1963) estimates that a reduction in contact time to one fifth of normal is necessary to produce any measurable difference in oxygen tension between alveolar gas and the blood at the end of the capillaries at rest. Measurements of the contact time in the present study showed changes of this degree only in the more severely affected patients, suggesting that restriction of the pulmonary vascular bed is not the major determinant of the low arterial oxygen saturation in pulmonary fibrosis, though it may be a contributory factor.

Uneven distribution of ventilation and perfusion in the lung is responsible for most of the difference between alveolar and arterial oxygen tensions in normal subjects (Briscoe, 1959; Asmussen and Nielsen, 1960 and 1961). These effects are greatly accentuated in pulmonary? fibrosis by focal involvement of airways and blood $\frac{C}{0}$ vessels, and many investigators have concluded $\overline{\frac{F}{5}}$ that the low arterial oxygen saturation in this $\widehat{\nabla}$ condition can be accounted for by the distribution disturbances (Motley, 1958 ; Holland and Blacket, 1960 ; Finley et al., 1962; West, 1963). The $\vec{O}$ changes in the components of gas transfer $\overrightarrow{\vec{C}}$ reported here must be interpreted in the light of $\vec{\omega}$ these findings. The single-breath method used to $\rightleftharpoons$ measure the transfer factor for carbon monoxide $\vec{x}$ is influenced by uneven ventilation, and in addi- $\vec{\bullet}$ tion local variations in capillary volume are $\dot{\sigma}$ probably produced by uneven blood flow in the lungs (Hamer, 1963b). These distribution effects 0 reduce the transfer factor by limiting the contact between alveolar gas and capillary blood (Burrows, $\vec{z}$ Niden, Mittman, Talley, and Barclay, 1960). If the ㅇ effect is similar at all levels of oxygen tension, $\stackrel{\Phi}{\triangle}$ both the components of gas transfer ( $D_{M}$ and $\mathrm{Vc}$ ) 음 will be similarly reduced. However, Burrows et al. (1960) suggest that the effect may be less at higher $\vec{\bullet}$ oxygen tensions. Breathing air, the carbon $\stackrel{\circ}{\perp}$ monoxide concentration will fall to low levels during breath holding in alveoli with a rapid uptake. At higher oxygen tensions, the reduced uptake will maintain higher carbon monoxide levels in these alveoli throughout breath holding, $\stackrel{\mathbb{D}}{\otimes}$ so the transfer factor will be greater than

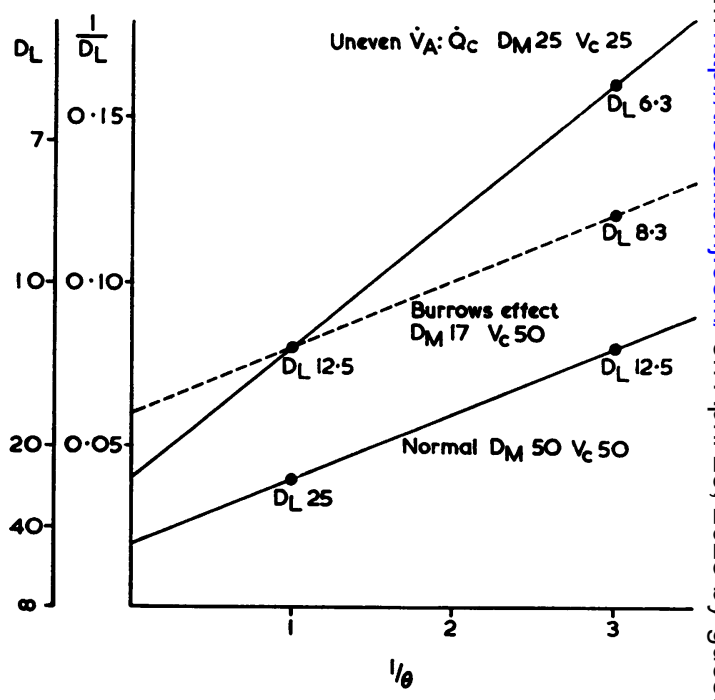

FIG. 4. Suggested mechanism by which a reduction in $D M$ can be produced by uneven distribution in the lungs. If $\bar{O}$ distribution effects are similar at all oxygen tensions, both $D_{M}$ and $V_{C}$ are reduced. However, if the effects are less at $\frac{O}{\Phi}$ higher oxygen tension, as suggested by Burrows et al. (1960), only $D_{M}$ is affected. 
expected. If this mechanism reduces the changes due to uneven distribution by approximately one third at high oxygen tensions, the effects of uneven distribution will be confined to the membrane component (DM) (Fig. 4).

In many patients with pulmonary sarcoidosis of relatively short duration (Hamer, 1963a), and in two patients with mild idiopathic pulmonary fibrosis reported here, the membrane component (DM) was found to be significantly impaired but the capillary volume (Vc) was normal. These findings might at first sight be taken to indicate interference with diffusion across the alveolarcapillary membrane, either by sarcoid deposits or diffuse fibrosis, but they can also be explained on the basis of uneven distribution of ventilation and perfusion. Even in normal subjects, measurements of the membrane component ( $D_{M}$ ) probably overestimate the resistance to diffusion across the alveolar-capillary membrane as uneven distribution effects are included in the measurement. Experimental studies of the effect of anaemia on perfused dog lungs (Burrows and Niden, 1963) and of movement of gases of different molecular weights (Chinard, Enns, and Nolan, 1961) confirm that there is in fact little resistance to diffusion. Although thickening of the alveolar walls in pulmonary fibrosis must greatly increase the diffusion pathway (Meessen, 1961 ; Schulz, 1962), Staub (1963) has estimated that the resistance to diffusion must be more than five times the normal value to produce any detectable fall in arterial oxygen tension. Changes in the membrane component $\left(D_{M}\right)$ of this order were frequent in the present study but are probably in the main a reflection of ventilation-perfusion disturbances. It seems unlikely that thickening of the alveolarcapillary membrane is playing more than a minor part in producing the low arterial oxygen saturations in these patients.

The small capillary volume $(\mathrm{Vc})$ found in most patients with pulmonary fibrosis or longstanding sarcoidosis (Hamer, 1963b) may also in part be due to distribution disturbances. However, the changes in the membrane component (DM) are similar to those found in patients with a normal capillary volume (Table IV), suggesting that the effects of uneven distribution are not grossly different in the two groups. A fall in the membrane component might be expected to accompany a reduction in capillary volume as the area available for diffusion is diminished. The relative constancy of the membrane component in these patients, and in physiological changes in capillary volume (Cotes, Snidal, and Shepard, 1960), gives further support to the suggestion that the resistance to diffusion does not play an important part in determining the membrane component of gas transfer.

\section{SUMMARY}

The components of the pulmonary gas transfer $\left(D_{L}\right)$ were measured in seven patients with diffuse interstitial pulmonary fibrosis and in two with carcinomatous infiltration of the lungs.

The membrane component of gas transfer ( $\left.D_{M}\right)$ was considerably impaired in all cases. This is interpreted as evidence of disturbances of distribution in the lungs rather than of a diffusion defect.

The pulmonary capillary volume (Vc) was also markedly diminished in most of these patients. However, cardiac catheterization confirmed that the changes were not sufficient to produce a serious reduction in the contact time between the blood and the alveolar gas.

The results are consistent with the suggestion that the fall in arterial oxygen saturation in diffuse pulmonary fibrosis is due to uneven distribution effects. The concept of 'alveolar-capillary block' should be discarded.

I am most grateful to Dr. Clifford Hoyle for his encouragement and for allowing me to study patients under his care.

\section{REFERENCES}

Asmussen, E., and Nielsen, M. (1960). Alveolo-arterial gas exchange at rest and during work at different $\mathrm{O}_{2}$ tensions. Acta physiol. scand., 50, 153.

(1961). The contribution of the distribution factor to the $\mathrm{A}-\mathrm{a} \mathrm{PO}_{2}$ difference (a correction). Ibid. 51,385 .

Austrian, R., McClement, J. H., Renzetti, A. D., Donald, K. W. Riley, R. L., and Cournand, A. (1951). Clinical and physiologic features of some types of pulmonary diseases with impairmen of alveolar-capillary diffusion : the syndrome of "alveolarcapillary block". Amer. J. Med., 11, 667.

Baldwin, E. deF., Cournand, A., and Richards, D. W. (1949). Pulmonary insufficiency II. A study of thirty-nine cases of pulmonary fibrosis. Medicine (Baltimore), 28, 1.

Bates, D. V., Varvis, C. J., Donevan, R. E., and Christie, R. V. (1960). Variations in the pulmonary capillary blood volume and membrane diffusion component in health and disease. J. clin. Invest., 39, 1401.

Briscoe, W. A. (1959). Comparison between alveolo arterial gradient predicted from mixing studies and the observed gradient. $J$. appl. Physiol., 14, 299.

Burrows, B. and Niden, A. H. (1963). Effects of anemia and hemorrhagic shock on pulmonary diffusion in the dog lung. Ibid., 18, 123. Non-uniform pulmonary diffusion as demonstrated by the carbon monoxide equilibration technique. Experimental results in man. J. clin. Invest., 39, 943.

Catterall, M., and Roweli, N. R. (1963). Respiratory function in progressive systemic sclerosis. Thorax, 18, 10.

Chinard, F. P., Enns, T., and Nolan, M. F. (1961). Diffusion and solubility factors in pulmonary inert gas exchanges. $J$. appl. Physiol., 16, 831 .

Cotes, J. E.'(1963). Terminology for exchange of gas in the lungs. Lancet, i1, 843.

Snidal, D. P., and Shepard, R. H. (1960). Effect of negative intra-alveolar pressure on pulmonary diffusing capacity. $J$. appl. Physiol., 15, 372.

- Finley, T. N., Swenson, E. W., and Comroe, J. H. (1962). The cause of arterial hypoxemia at rest in patients with "alveolar-capillary block syndrome". J. clin. Invest., 41, 618. 
Hamer, N. A. J. (1962). The effect of age on the components of the pulmonary diffusing capacity. Clin. Sci., 23, 85 .

- (1963a). Changes in the components of the diffusing capacity in pulmonary sarcoidosis. Thorax, 18, 275 .

- $(1963 \mathrm{~b})$. Changes in the absorption of carbon monoxide in the lungs after breathing oxygen. Clin. Sci., 25, 385.

Hamman, L., and Rich, A. R. (1944). Acute diffuse interstitial fibrosis of the lungs. Bull. Johns Hopk. Hosp., 74, 177.

Holland, R. A. B., and Blacket, R. B. (1960). Pulmonary function in the Hamman-Rich syndrome. Amer. J. Med., 29, 955.

Jones, R. S., and Meade, F. (1961). A theoretical and experimental analysis of anomalies in the estimation of pulmonary diffusing capacity by the single breath method. Quart. J exp. Physiol., 46, 131 .

Kreuzer, F., and Yahr, W. Z. (1960). Influence of red cell membrane on diffusion of oxygen. J. appl. Physiol., 15, 1117.

- Livingstone, J. L., Lewis, J. G., Reid, L., and Jefferson, K. E. (1964). Diffuse interstitial pulmonary fibrosis. Quart. J. Med., 33, 71.

Luchsinger, P. C., Katz, S., McCormick, G. F., Donohoe, R. F., and Moser, K.M. (1959). Cardiorespiratory studies in HammanRich syndrome. Dis. Chest, 35, 52 .

- Moser, K. M. Bühlmann, A and Rossier, P. H. (1957). The interrelationship between cor pulmonale, capillary bed restriction and diffusion insufficiency for oxygen in the lung. Amer. Heart J., 54, 106.

McGrath, M. W. and Thomson, M. L. (1959). The effect of age, body size and lung volume change on alveolar-capillary permeability and diffusing capacity in man. J. Physiol. (Lond.)., 146, 572.

McNeill, R. S., Rankin, J., and Forster, R. E. (1958). The diffusing capacity of the pulmonary membrane and the pulmonary capillary blood volume in cardiopulmonary disease. Clin. Sci., 17, 465 .

Marks, A., Cugell, D. W., Cadigan, J. B., and Gaensler, E. A. (1957). Clinical determination of the diffusion capacity of the lungs. Amer. J. Med., 22, 51.

Marshall, R. Smellie, H. Baylis, J. H., Hoyle, C., and Bates, D. V. (1958). Pulmonary function in sarcoidosis. Thorax, 13,48.

Meessen, H. (1961). The pathomorphology of diffusion processes in the lung. Stan. med. Bull., 19, 19.

Motley, H. L. (1958). Studies on the nature of the arterial blood oxygen unsaturation in chronic pulmonary disease. Dis. Chest. 33, 58
Needham, C. D., Rogan, M. C., and McDonald, I. (1954). Normal standards for lung volumes, intrapulmonary gas-mixing, and maximum breathing capacity. Thorax, 9, 313 .

Ogilvie, C. M., Forster, R. E., Blakemore, W. S., and Morton, J. W. (1957). A standardized breath holding technique for the clinical $\bar{\omega}$ measurement of the diffusing capacity of the lung for carbon monoxide. J. clin. Invest., 36, 1 .

Rossier, P. H., Bühlmann, A., and Luchsinger, P. (1954). Bemerkungen über Diffusionsstörungen der Lunge. Schweiz. med. CS Wschr., 84, 25.

Roughton, F. J. W., and Forster, R. E. (1957). Relative importance $\vec{O}$ of diffusion and chemical reaction rates in determining rate of exchange of gases in the human lung, with special reference to true diffusing capacity of pulmonary membrane and volume of blood in the lung capillaries. J. appl. Physiol., 11, 290.

Rubin, E. H., and Lubliner, R. (1957). The Hamman-Rich syndrome: review of the literature and analysis of 15 cases. Medicine (Baltimore), 36, 397.

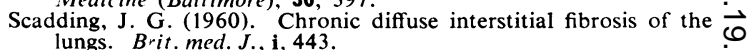

Schulz, H. (1962). Some remarks on the sub-microscopic anatony $\sigma$ and pathology of the blood-air pathway in the lung. Ciba ir Foundation Symposium on Pulmonary Structure and Function. $\bigcirc$ p. 205. Ed. de Reuck, A. V. S. and O'Connor, M. Churchill, London.

Siösteen, S. M. and Sjöstrand, T. (1951). A method for the determination of low concentrations of $\mathrm{CO}$ in the blood and the relation between the $\mathrm{CO}$-concentration in the blocd and that in the alveolar air. Acta physiol. scand., 22, 129.

Sirs, J. A (1963). Influence of metabolism on uptake of CO and $\mathrm{O}_{2}$ by hemoglobin in erythrocytes. J. appl. Physiol., 18, 175

Staub, N. C. (1963). Alveolar-arterial oxygen tension gradient due

to diffusion. Ibid., 18, 673. and chemical reaction rates in $\mathrm{O}_{2}$ uptake in the lung. Ibid., 17, 21.

Thews, G., and Niesel, W. (1959). Zur Theorie der Sauerstoffdiffusion صै im Erythrocyten. Pfügers Arch. ges. Physiol, 268, 318.

Turino, G. M., Bergofsky, E. H., Goldring, R. M., and Fishman, A. P. (1963). Effect of exercise on pulmonary diffusing capacity. J. appl. Physiol., 18, 447.

-West, J. B. (1963). Blood-flow, ventilation, and gas exchange in the lung. Lancet, ii, 1055. 